\title{
Epidemiology of Alzheimer Disease
}

\author{
Richard Mayeux and Yaakov Stern
}

Gertrude H. Sergievsky Center, Taub Institute for Research on Alzheimer's Disease and the Aging Brain, Columbia University Medical Center, New York, New York 10032

Correspondence: ys11@columbia.edu

The global prevalence of dementia has been estimated to be as high as 24 million, and is predicted to double every 20 years until at least 2040. As the population worldwide continues to age, the number of individuals at risk will also increase, particularly among the very old. Alzheimer disease is the leading cause of dementia beginning with impaired memory. The neuropathological hallmarks of Alzheimer disease include diffuse and neuritic extracellular amyloid plaques in brain that are frequently surrounded by dystrophic neurites and intraneuronal neurofibrillary tangles. The etiology of Alzheimer disease remains unclear, but it is likely to be the result of both genetic and environmental factors. In this review we discuss the prevalence and incidence rates, the established environmental risk factors, and the protective factors, and briefly review genetic variants predisposing to disease.

\begin{abstract}
lzheimer disease is characterized by progressive cognitive decline usually beginning with impairment in the ability to form recent memories, but inevitably affecting all intellectual functions and leading to complete dependence for basic functions of daily life, and premature death. The pathological manifestations of Alzheimer disease include diffuse and neuritic extracellular amyloid plaques and intracellular neurofibrillary tangles accompanied by reactive microgliosis, dystrophic neurites, and loss of neurons and synapses (see Serrano-Pozo et al. 2011). While these pathological lesions do not fully explain the clinical features of the disease, it has been hypothesized that alterations in the production and processing of amyloid $\beta$-protein may be the principal initiating factor. The underlying causes of these multifaceted changes remain unknown, but advancing age, and genetic and nongenetic
\end{abstract}

antecedent factors are thought to play important roles. Alzheimer disease is the most frequent cause of dementia in Western societies. In the US, approximately 5.5 million people are affected, and the prevalence worldwide is estimated to be as high as 24 million. Given that both established and developing nations are rapidly aging, the frequency is expected to double every 20 years until 2040. The magnitude of the impending rise owing to societal aging is considerable and will be a costly public health burden in the years to come.

\section{DEFINITIONS AND CRITERIA}

In 1984, representatives from the National Institute of Neurological and Communicative Disorders and Stroke and the Alzheimer Disease and Related Disorders Association (NINCDSADRDA) developed a uniform set of criteria

Editors: Dennis J. Selkoe, Eckhard Mandelkow, and David M. Holtzman

Additional Perspectives on The Biology of Alzheimer Disease available at www.perspectivesinmedicine.org

Copyright (C) 2012 Cold Spring Harbor Laboratory Press; all rights reserved; doi: 10.1101/cshperspect.a006239

Cite this article as Cold Spring Harb Perspect Med 2012;2:a006239 
to enable clinicians and researchers to maintain consistency in the diagnosis. They included aspects of medical history, clinical examination, neuropsychological testing, and laboratory assessments (McKhann et al. 1984). These criteria have been remarkably reliable and valid for the diagnosis of $\mathrm{AD}$ over the past three decades (Galasko et al. 1994; Lim et al. 1999). The criteria were developed with the intent of accurately associating the clinical symptoms with the neuropathological manifestations after death. Levels of certainty were established that were labeled as definite for autopsy-confirmed disease, probable for the typical clinical syndrome without intervening issues and possible for diagnoses complicated by disorders that might contribute to the dementia. The criteria facilitated estimates of the prevalence and incidence rates of clinically diagnosed probable and possible $\mathrm{AD}$.

The NINCDS-ADRDA criteria have very recently been updated (McKhann et al. 2011). With major advances in neuropsychological assessment, brain imaging and the neuropathological, biochemical and genetic understanding of this disease, revisions were considered a necessity. The breadth of the $\mathrm{AD}$ phenotype in society is greater than was previously thought. For example, neuropathological changes may precede clinical dementia by a decade or more. The growing use of brain imaging and cerebrospinal fluid biomarkers (see below) may yield both higher specificity and sensitivity in the diagnosis and thus are considered in the updated diagnostic criteria, especially when used for clinical research. It has become increasingly clear that cerebrovascular disease can coexist with $\mathrm{AD}$ to a greatly varying extent, further contributing to the cognitive and physical dysfunction.

A set of newly proposed criteria are similar to, but distinct from, those in the 1984 NINCDS-ADRDA criteria, with updates that include the recognition of both amnestic and nonamnestic symptom onset and alterations in numerous other cognitive domains. Further, cerebrovascular disease is now recognized as a contributor to dementia, defined by a history of a stroke temporally related to the onset or worsening of cognitive impairment, the presence of multiple or extensive infarcts, or severe burden of hyperintense white matter lesions by MRI. Accordingly, the presence of substantial cerebrovascular pathology reduces the certainty of a clinical diagnosis of $\mathrm{AD}$ to possible. Hallucinations, delusions, Parkinsonlike motor manifestations and realted findings can suggest dementia with Lewy bodies or other forms of dementia (see Tarawneh and Holtzman 2011; Weintraub et al. 2011).

In this chapter, we will discuss the prevalence and incidence rates of AD disease in developed and developing countries and summarize the evidence for numerous antecedent risk factors, protective factors and genetic risk factors.

\section{FREQUENCY OF ALZHEIMER DISEASE}

In 2005, Alzheimer Disease International commissioned an international group of experts to reach a consensus on dementia prevalence and estimated incidence in 14 World Health Organization regions, based on epidemiological data acquired over recent years. The results suggested that 24.2 million people lived with dementia at that time, with 4.6 million new cases arising every year (Ferri et al. 2005). North America and Western Europe have at age 60 the highest prevalence of dementia (6.4 and $5.4 \%$ of the population at age 60), followed by Latin America $(4.9 \%)$ and China and its developing western-Pacific neighbors (4.0\%). The annual incidence rates (per 1000) for these countries were estimated at 10.5 for North America, 8.8 for Western Europe, 9.2 for Latin America and 8.0 for China and its developing western-Pacific neighbors, increasing exponentially with age in all countries, especially through the seventh and eighth decades of life.

The prevalence rates for $\mathrm{AD}$ also rise exponentially with age, increasing markedly after 65 years. There is almost a 15 -fold increase in the prevalence of dementia, predominately Alzheimer disease, between the ages of 60 and 85 years (Evans et al. 1989). Compared with Africa, Asia and Europe, the prevalence of AD appears to be much higher in the US, which may relate to methods of ascertainment. The prevalence may be higher among African-American and 
Hispanic populations living in the US, but lower for Africans in their homelands, for reasons that remain uncertain (Ogunniyi et al. 2000; Hendrie et al. 2001).

In 1998, Brookmeyer et al. estimated the age-specific incidence rates of $\mathrm{AD}$ based on studies in Boston, Framingham, Rochester, and Baltimore. These rates doubled every 5 years after the age of 60 and rose from about $0.17 \%$ per year at age 65 to $0.71,1.0$, and $2.92 \%$ per year, respectively, at 75,80 , and 85 (Brookmeyer et al. 1998). This observation is consistent with the vast majority of studies that have estimated the age-specific incidence of $\mathrm{AD}$ by sex and by ethnic group (Fig. 1; Bachman et al. 1993; Letenneur et al. 1994; Brayne et al. 1995; Hebert et al. 1995; Aevarsson and Skoog 1996; Fratiglioni et al. 1997; Andersen et al. 1999; Copeland et al. 1999; Launer et al. 1999; Ganguli et al. 2000; Kawas et al. 2000; Lobo et al. 2000; Chandra et al. 2001; Hendrie et al. 2001; Tang et al. 2001; Di Carlo et al. 2002; Edland et al. 2002; Knopman et al. 2002; Kukull et al. 2002; Fitzpatrick et al. 2004; Lopez-Pousa et al. 2004; Nitrini et al. 2004; Ravaglia et al. 2005a; Jellinger and Attems 2010).

Two factors contribute to the difficulty in establishing accurate incidence rates of AD: (1) determining the age at onset; and (2) defining a disease-free population. Nonetheless, studies illustrate the consistent increase in incidence rates with age from approximately $0.5 \%$ per year among individuals aged $65-70$ to approximately $6-8 \%$ for individuals over age 85 . The rapid rise in the frequency of $\mathrm{AD}$ with advancing age, combined with the relatively long duration of the illness, accounts in large part for the high prevalence of the disease worldwide. Improvement and standardization of diagnostic methods have provided a means to compare estimates of the frequency of $\mathrm{AD}$ across various populations.

\section{ANTECEDENT RISK FACTORS THAT INCREASE THE RISK OF ALZHEIMER DISEASE}

A large number of factors has been associated with increased risk of $\mathrm{AD}$, but among those, cerebrovascular disease and it antecedents are the most consistently reported (Table 1). A history of diabetes, hypertension, smoking, obesity, and dyslipidemia have all been found to increase risk. Interestingly cerebrovascular disease, including large cortical infarcts, single strategically placed infarcts, multiple small infarcts, cerebral hemorrhage, cortical changes owing to hypoperfusion, white matter changes and vasculopathies, are all antecedents to dementia in general (Barba et al. 2000; de Koning et al. 2000; Desmond et al. 2000, 2002; Zhu et al. 2000; Henon et al. 2001; Klimkowicz et al. 2002; Honig et al. 2003; Liebetrau et al. 2003; Ivan et al. 2004; Linden et al. 2004; Srikanth et al. 2004; Tang et al. 2004; Zhou et al. 2004; de Koning et al. 2005; Kuller et al. 2005; Gamaldo et al. 2006; Jin et al. 2006; Simons et al. 2006; Srikanth et al. 2006; Yip et al. 2006; Jin et al. 2008; Reitz et al. 2008; Rastas et al. 2010).

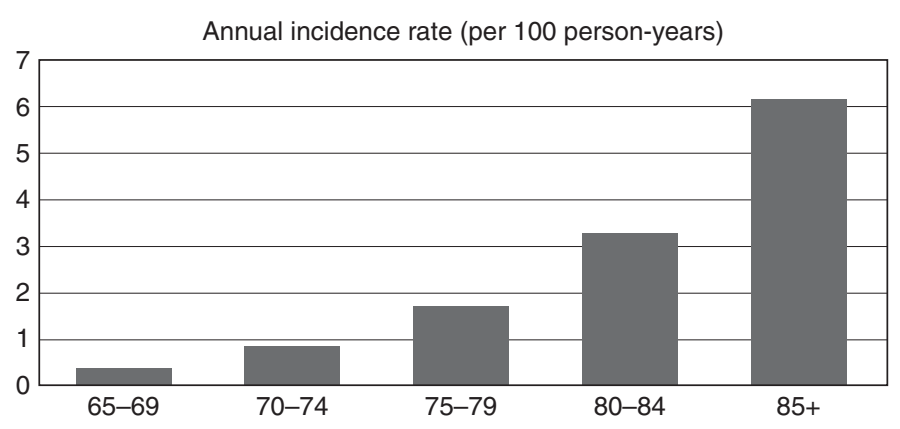

Figure 1. The annual incidence rate (per 100 person-years) for Alzheimer disease. This graph is an estimate of the data collected in 24 published studies. 
Table 1. Factors that modify the risk of Alzheimer disease

\begin{tabular}{|c|c|c|}
\hline Antecedent & Direction & Possible mechanisms \\
\hline Cardiovascular disease & Increased & $\begin{array}{l}\text { Parenchymal destruction } \\
\text { Strategic location } \\
\uparrow A \beta \text { deposition }\end{array}$ \\
\hline Smoking & Increased & $\begin{array}{l}\text { Cerebrovascular effects } \\
\text { Oxidative stress }\end{array}$ \\
\hline Hypertension & Increased and decreased & Microvascular disease \\
\hline Type II diabetes & Increased & $\begin{array}{l}\text { Cerebrovascular effect } \\
\text { Insulin and } A \beta \text { compete for clearance }\end{array}$ \\
\hline Obesity & Increased & Increased risk of type II diabetes inflammatory \\
\hline Traumatic head injury & Increased & $\uparrow A \beta$ and amyloid precursor protein deposition \\
\hline Education & Decreased & Provides cognitive reserve \\
\hline Leisure activity & Decreased & Improves lipid metabolism, mental stimulation \\
\hline Mediterranean diet & Decreased & Antioxidant, anti-inflammatory \\
\hline Physical activity & Decreased & Activates brain plasticity, promotes brain vascularization \\
\hline
\end{tabular}

\section{Cerebrovascular Disease}

While it is clear that cerebrovascular disease may present with manifestations resembling dementia, purely vascular dementia is uncommon. More often cerebrovascular disease co-exists with $\mathrm{AD}$, so that evidence of both vascular disease and prototypical $\mathrm{AD}$ manifestations is present (Schneider and Bennett 2010). Pendlebury and Rothwell (2009) analyzed data from several hospital- and population-based cohorts (7511 patients) and estimated a frequency of new-onset dementia to be approximately $7 \%$ following a first stroke. Interestingly, the twofold increased risk of dementia after incident stroke was independent of the level or the rate of change of prestroke cognitive function, suggesting that prestroke cognitive function is not a major determinant of the effect of stroke on the risk of poststroke dementia (Reitz et al. 2008). The proposed mechanisms by which stroke could lead to cognitive impairment include destruction of brain parenchyma with atrophy (Fein et al. 2000; Jellinger 2002), damage in strategic locations that leads to amnestic syndromes, such as thalamic strokes, an increase in $A \beta$ deposition and the combination of vascular and Alzheimer-type pathology (Blennow et al. 2006). As one possible mechanism for an increase in $A \beta$, there is evidence from rodent models of ischemia and hypoxia owing to hypoperfusion that a resulting overexpression of p25 and cdk5 increases levels of BACE1, which in turn increases amyloid precursor protein (APP) processing (Wen et al. 2007, 2008).

White matter hyperintensities are frequently observed by MRI in patients with dementia, but the mechanisms by which white matter changes contribute to cognitive decline are unclear. Moreover because hypertension, diabetes and microvasuclar disease are each associated with these changes, there is no clear process to explain the effect on cognition or their role in Alzheimer disease. Thalamic vascular disease can lead to lower performance on cognitive tasks, particularly those associated with frontal and temporal lobe function, including memory storage and retrieval (Swartz et al. 2008; Wright et al. 2008).

\section{Hypertension}

Cross-sectional and longitudinal studies implicate blood pressure as a possible contributor to late-life dementia. Observational studies of the association between elevated blood pressure during middle age and late-life cognitive impairment suggest that mid-life hypertension increases the risk of late-life dementia (Kilander et al. 2000; Launer et al. 2000; Wu et al. 2003; Yamada et al. 2003; Elias et al. 2004; Whitmer et al. 2005b). When hypertension is assessed in later life, the association is somewhat ambiguous, in that both high and abnormally low 
blood pressure are associated with dementia (Skoog et al. 1996; Knopman et al. 2001; Morris et al. 2001; Ruitenberg et al. 2001; Tyas et al. 2001; Bohannon et al. 2002; Lindsay et al. 2002; Posner et al. 2002; Elias et al. 2003; Kuller et al. 2003; Piguet et al. 2003; Qiu et al. 2003; Reinprecht et al. 2003; Verghese et al. 2003a; Hebert et al. 2004; Solfrizzi et al. 2004; Tervo et al. 2004; Borenstein et al. 2005; Petitti et al. 2005; Waldstein et al. 2005). With Alzheimer disease onset and progression, blood pressure begins to decrease, possibly related to vessel stiffening, weight loss, and changes in the autonomic regulation of blood flow. Hypertension is a treatable medical disorder, but clinical trials of antihypertensive medications in $\mathrm{AD}$ patients have been attempted with inconsistent results (Forette et al. 2002; Lithell et al. 2003; Tzourio et al. 2003; Peters et al. 2010).

\section{Type II Diabetes}

The presence of type II diabetes is associated with a approximately twofold increased risk of $\mathrm{AD}$ (risk ratios vary between 1.5 and 4.0; Luchsinger et al. 2001; Peila et al. 2002; Farris et al. 2003; Luchsinger et al. 2004a). It has been suggested that diabetes directly affects A $\beta$ accumulation in the brain because hyperinsulinemia, which accompanies type II diabetes, disrupts brain $A \beta$ clearance by competing for the insulin-degrading enzyme (Selkoe 2000; Farris et al. 2003). Receptors for advanced glycation end-products, which also play a role in the pathogenesis of diabetes, are present in cels associated with senile plaques and neurofibrillary tangles have been shown to be one example of a cell surface receptor for A $\beta$. Excess adipose tissue may also predispose to type II diabetes by producing adipokines critical to metabolism and cytokines important in inflammation. Adiponectin, leptin, resistin, TNF- $\alpha$ and IL- 6 are also produced and correlate with insulin resistance and hyperinsulinemia, which in turn may directly or indirectly affect $\mathrm{AD}$ risk (Trujillo and Scherer 2005; Yu and Ginsberg 2005). A meta-analysis of longitudinal studies examining type II diabetes and other disorders of glucose or insulin levels found a pooled effect size for diabetes of 1.54 in increasing $\mathrm{AD}$ risk (95\% confidence interval, CI, 1.33-1.79; $z=$ 5.7; $p<.001$; Profenno et al. 2009).

Reger et al. (2008) showed that the administration of intranasal insulin improved cognitive performance in the early phases of $\mathrm{AD}$ and in patients with amnestic mild cognitive impairment, as did a 6-month trial of the PPAR- $\gamma$ agonist, rosiglitazone (Watson et al. 2005). Another study (Risner et al. 2006) in patients with $\mathrm{AD}$ lacking the APOE- 84 allele showed significant although small improvements in cognitive and functional improvement in response to rosiglitazone, whereas in a study by Sato et al. (2009), treatment with $15-30 \mathrm{mg}$ pioglitazone daily for 6 months led to improvements in cognitive function and regional cerebral blood flow in the parietal lobe.

\section{Body Weight}

Several cross-sectional and case-control studies found that low body mass index or being underweight were apparent risk factors for dementia and age-related brain changes such as atrophy (Faxen-Irving et al. 2005). In contrast several prospective studies linked both low and high body weight, weight loss and weight gain to risk of AD (Nourhashemi et al. 2002, 2003; Gustafson et al. 2003; Bagger et al. 2004; Brubacher et al. 2004; Buchman et al. 2005; Goble 2005; Jeong et al. 2005; Kivipelto et al. 2005; Razay and Vreugdenhil 2005; Rosengren et al. 2005; Stewart et al. 2005; Tabet 2005; Whitmer et al. 2005a; Waldstein and Katzel 2006; Arbus et al. 2008; Atti et al. 2008). The strongest effect was in a meta-analysis associating obesity (assessed by high body mass index) and the risk of $\mathrm{AD}$ (odds ratio, OR, 1.59 95\% CI 1.02-2.5; $z=$ 2.0; $p=.042$ ) (Profenno et al. 2009). The mechanisms by which body weight alters disease risk are unknown, but may include effects such as insulin resistance or the co-incidence of type II diabetes.

\section{Smoking}

Case-control studies initially suggested that smoking lowers the risk of Alzheimer disease, but subsequent prospective studies showed an 
increased risk or no association (Doll et al. 2000). Smoking may increase the risk of dementia by augmentation of cholinergic metabolism, that is, up-regulating cholinergic nicotinic receptors in the brain (Whitehouse et al. 1988). Cholinergic deficits, characterized by reduced levels of acetylcholine, choline acetyl transferase and/or nicotinic acetyl choline receptors, are invariably found in $\mathrm{AD}$ brains. However, nicotine itself increases acetylcholine release, elevates the number of nicotinic receptors, and improves attention and information processing. These actions may be opposed by elevated oxidative stress caused by smoking, and oxidative stress has been implicated as a putative $\mathrm{AD}$ mechanism (Rottkamp et al. 2000; Perry et al. 2002) through the generation of free radicals and affecting inflammatoryimmune systems, which in turn can activate phagocytes that generate further oxidative damage (Traber et al. 2000).

\section{Traumatic Brain Injury}

Compared with those without a history of trauma, individuals having suffered traumatic brain injury have a higher risk of dementia, particularly those who carry the APOE- $\varepsilon 4$ allele (Koponen et al. 2004). A meta-analyses demonstrated that the risk of dementia is higher among men (but not women) with a history of traumatic brain injury (Fleminger et al. 2003). Postmortem and experimental studies do support a link: After human brain injury, both $A \beta$ deposition (Hartman et al. 2002; Iwata et al. 2002; Stone et al. 2002) and intraneuronal tau pathology are increased, even in younger patients (Smith et al. 2003). In addition, CSF A $\beta$ levels are elevated and APP is overproduced (Emmerling et al. 2000; Franz et al. 2003).

\section{PROTECTIVE FACTORS THAT REDUCE RISK OF ALZHEIMER DISEASE}

\section{Cognitive Reserve}

Individuals with intellectually enriched lifestyles, such as those with high educational and/or occupational attainment, have a reduced risk of expressing AD pathology clinically. While several studies reported no association between educational level and risk of AD (Hall et al. 2000; Chandra et al. 2001), a lower risk of dementia in general in subjects with higher education has been reported by several others worldwide (Evans et al. 1993, 1997; Letenneur et al. 1994, 1999; Stern et al. 1994; White et al. 1994; Qiu et al. 2001).

There is also evidence for a role of education in age-related cognitive decline, with several studies of "normal aging" reporting slower cognitive and functional decline in individuals with higher educational attainment (Chodosh et al. 2002). These studies suggest that the same education-related factors that delay the onset of AD-type dementia also allow individuals to cope more effectively with brain changes encountered in normal aging. In an ethnically diverse cohort of nondemented elders in New York City, increased literacy was also associated with slower decline in memory, executive function, and language skills (Manly et al. 2005).

Numerous studies have also explored the relationship between leisure activities and incident dementia. Community activities and gardening were also protective for incident dementia in China (Zhang et al. 1999). Having an extensive social network was protective for the development of dementia (Fratiglioni et al. 2004), and engagement in mental, social, and other productive activities was associated with decreased risk of incident dementia (Wang et al. 2002). Participation in a variety of leisure activities characterized as intellectual (e.g., reading, playing games, going to classes) or social engagements (e.g., visiting friends or relatives) was assessed in another population study of nondemented elderly in New York (Scarmeas et al. 2001). During follow-up, subjects with high leisure activity had 38\% less risk of developing dementia. In another prospective study, frequency of participation in common cognitive activities (i.e., reading a newspaper, magazine, or book) was assessed at baseline for 801 elderly Catholic nuns, priests and brothers without dementia (Wilson et al. 2002a). Finally, in another prospective cohort from New York, 
participation in leisure activities, particularly reading, playing board games or musical instruments, and dancing, was associated with a reduced risk of incident dementia (Verghese et al. 2003b). Increased participation in cognitive activities was also associated with reduced rates of memory decline in this study.

A meta-analysis examined cohort studies of the effects of education, occupation, premorbid IQ and mental activities on dementia risk (Valenzuela and Sachdev 2005). A summary analysis was based on an integrated total of 29,279 individuals from 22 studies. The median follow-up was 7.1 years. The summary odds ratio for incident dementia for individuals with high brain reserve compared with low brain reserve was 0.54 (95\% CI $0.49-0.59$, $p<0.0001$ ), that is, a decreased risk of $46 \%$. Eight out of 33 data sets showed no significant effect, whereas 25 out of 33 demonstrated a significant protective effect. The authors found a significant negative association between incident dementia risk (based on differential education) and the overall dementia rate for each cohort $(r=-0.57, p=0.04)$, indicating that in negative studies there was a lower overall risk of incident dementia in the cohort.

In contrast to the studies above, in which greater cognitive reserve was associated with better outcomes, a series of studies of patients with $\mathrm{AD}$ suggested that those with higher reserve have poorer outcomes (Table 1). In prospective studies of $\mathrm{AD}$ subjects matched for clinical severity at baseline (Geerlings et al. 1999; Stern et al. 1999), patients with greater education or occupational attainment died sooner than those with less attainment. Similarly, higher educational or occupational attainment (Stern et al. 1999; Scarmeas et al. 2006a), increased engagement in leisure activities (Helzner et al. 2007), and greater lifetime cognitive activity (Wilson et al. 2010) have each been associated with more rapid cognitive decline in patients with diagnosed AD. Although at first these findings appear contraintuitive, they are consistent with the cognitive reserve hypothesis. The hypothesis predicts that, at any level of assessed clinical severity, the underlying pathology of Alzheimer disease is more advanced in patients with higher than those with less cognitive reserve. This would result in the clinical disease emerging when pathology was more advanced, as suggested by the incidence studies reviewed above. This disparity in degree of pathology would be present at more advanced clinical stages of the disease as well. At some point the greater degree of pathology in the high-reserve patients would result in more rapid death. Higher educational attainment and greater engagement in leisure activities and lifetime cognitive activities have also been associated with more rapid cognitive decline in patients with Alzheimer disease.

\section{Diet}

Dietary fats can increase cholesterol levels, which in turn can increase vascular risk in the brain. This sequence may also increase the risk of AD (Sparks et al. 2000). Intake of saturated fats in the fifth (highest) quintile compared with the first quintile of dietary fats was associated with a doubling of risk of incident Alzheimer disease. Trans-unsaturated fats were associated with a 3-times-higher risk of developing $\mathrm{AD}$, whereas the highest intake of $n-6$ polyunsaturated fats and monounsaturated fat reduced AD risk (Morris et al. 2003). An increased risk of $\mathrm{AD}$ has also been associated with higher intake of total and saturated fat, with no evidence of an association with polyunsaturated fat (Luchsinger et al. 2002).

Omega-3 fatty acids stems are essential dietary components in early brain development. Many studies have found that consumption of fish or omega- 3 fatty acids is associated with a reduced risk of AD (Morris et al. 2003; Schaefer et al. 2006; van Gelder et al. 2007). For example, a study in France found that weekly consumption of fish was associated with reduced AD risk, and regular consumption of omega-3 rich oils was associated with increased risk of all causes of dementia (Barberger-Gateau et al. 2007).

Two studies found a lower risk of Alzheimer disease in individuals with a higher dietary intake of vitamin D (Engelhart et al. 2002; Morris et al. 2002). This association was not 
noted in a third study, perhaps because the level of vitamin D intake was lower (Luchsinger et al. 2003).

Total homocysteine has also been inconsistently associated with $\mathrm{AD}$ (Luchsinger et al. 2004b; Seshadri 2006; Reitz et al. 2009). Concentrations of homocysteine are largely determined by certain B vitamins. Based on folate levels measured in serum, there was preliminary evidence from two studies that low folate levels are associated with increased $\mathrm{AD}$ risk (Wang et al. 2001; Ravaglia et al. 2005b). Some studies that used estimated dietary intake of folate and $B$ vitamins based on self-reported information reported conflicting results. One reported an association between higher intake of folate and reduced risk of $\mathrm{AD}$ (Luchsinger et al. 2007), whereas another did not find a significant reduction in AD risk associated with folate intake (Morris et al. 2006). Neither study found an association between vitamins B6 or B12 and risk of $\mathrm{AD}$.

Inconsistencies in the existing literature regarding some of the above dietary elements and $\mathrm{AD}$ risk may be a result of failure to consider possible additive and interactive (antagonistic or synergistic) effects among nutritional components, which may be better captured in a composite dietary pattern such as the Mediterranean diet. The latter is characterized by high intake of vegetables, legumes, fruits, and cereals; high intake of unsaturated fatty acids (mostly in the form of olive oil), but low intake of saturated fatty acids; a moderately high intake of fish; a low-to-moderate intake of dairy products (mostly cheese or yogurt); a low intake of meat and poultry; and regular but moderate amounts of ethanol, primarily in the form of wine and generally during meals (Trichopoulou et al. 2003). In one study (Scarmeas et al. 2006b), higher adherence to the Mediterranean diet was associated with lower risk of $\mathrm{AD}$ (hazard ratio, 0.91 ; 95\% CI, 0.83-0.98; $p=0.015$ ). Compared with subjects in the lowest Mediterranean diet tertile, subjects in the middle tertile had an AD hazard ratio of 0.85 ( $95 \%$ CI, $0.63-$ 1.16) and those in the highest tertile had a hazard ratio of 0.60 (95\% CI, 0.42-0.87) ( $p$ for trend $=0.007)$. In a follow-up analysis, the
Mediterranean diet was also associated with a reduced risk of developing mild cognitive impairment and of progression from mild cognitive impairment to AD (Scarmeas et al. 2009).

\section{Physical Activity}

Exercise can enhance learning in both young and aged animals (van Praag et al. 1999), activate brain plasticity mechanisms, remodel neuronal circuitry in the brain (Cotman and Berchtold 2002), promote brain vascularization (Black et al. 1990), and stimulate neurogenesis (van Praag et al. 1999). It may also increase neuronal survival and resistance to brain insults (Carro et al. 2001), increase levels of brainderived neurotrophic factor, mobilize gene expression profiles that would be predicted to benefit brain plasticity (Cotman and Berchtold 2002), and reduce levels of C-reactive protein and interleukin-6, two inflammatory markers (Ford 2002; Reuben et al. 2003). A Cochrane review (Angevaren et al. 2008) found that eight of 11 random, controlled trials of exercise in older people without known cognitive impairment reported that aerobic exercise interventions were associated with improvements in cognitive function.

Although some studies have failed to detect an association between physical activity and dementia (Wang et al. 2002; Wilson et al. 2002a; Verghese et al. 2003b), others have observed a beneficial role (Podewils et al. 2005; Rovio et al. 2005; Larson et al. 2006; Wang et al. 2006). A study of 1880 community-dwelling elders without dementia living in New York City investigated the combined association of diet and physical activity with Alzheimer risk. A combination of adherence to a strict Mediterranean-type diet and regular physical activity (compared with no or minimal physical activity) was associated with a significant reduction in risk of $\mathrm{AD}$.

\section{Cognitive Enhancement}

Several studies have specifically examined the potential effects of cognitive engagement on the risk of $\mathrm{AD}$ (Wilson et al. 2002b, 2007; 
Verghese et al. 2003b; Akbaraly et al. 2009). The studies used self-report of the frequency of involvement in specific activities that potentially have a cognitive component. In the Three-City cohort study, analyses were carried out on 5698 dementia-free participants aged 65 and over. Stimulating leisure activities were significantly associated with a reduced risk of $\mathrm{AD}$ (hazard ratio $(\mathrm{HR})=0.39$ ). This finding was independent of other proxies of cognitive reserve and remained significant after adjusting for vascular risk factors, depressive symptoms and physical functioning.

\section{GENETIC EPIDEMIOLOGY}

\section{Rare Variants}

Rare mutations in three genes have been firmly implicated in familial early-onset disease: $A P P$, PSEN1, and PSEN2 (Table 2; Goate et al. 1991; Levy-Lahad et al. 1995a,b; Rogaev et al. 1995; Sherrington et al. 1995, 1996). These mutations have high penetrance, are mostly inherited in an autosomal dominant pattern and lead with certainty to enhanced relative levels of the $A \beta 42$ peptide, its aggregation and an early onset of disease, typically beginning in the fourth or fifth decade of life. APP mutations account for an even smaller fraction (less than $1 \%$ of all $\mathrm{AD}$ patients). Rare variants such as these are occasionally seen in families of patients with familial Alzheimer disease having later onset (Athan et al. 2001). All APP missense mutations influence APP proteolytic processing and/or aggregation, because they are positioned in or near the $A \beta$-coding exons (16 and 17) of APP (see AD Mutation Database, http://www. molgen.vib-ua.be/ADMutations/). The mutation spectrum also includes microduplication at the APP locus on Ch 21. At the time of writing, 182 different $\mathrm{AD}$-related mutations in 401 families have been identified in PSEN1, whereas only 14 mutations in 23 families were detected in PSEN2 (http://www.molgen.vib-ua. be/ADMutations/). The majority of PSEN mutations are single-nucleotide substitutions, but small deletions and insertions have also been described. PSEN mutations alter the $\gamma$-secretase-mediated proteolytic cleavage of $A P P$, resulting in an increased $A \beta_{42} / A \beta_{40}$ ratio by an increase in $A \beta_{42}$ and/or a decrease in $A \beta_{40}$, suggesting a partial loss-of-function mechanism rather than a gain-of-function in PSEN (see Tanzi 2011 for a detailed review). Although mutations in these three genes represent rare causes of $\mathrm{AD}$, their discovery greatly supported a pivotal role for $A \beta$ in the pathogenesis of AD. According to this amyloid (or $\mathrm{A} \beta$ hypothesis), neurodegenerative processes are the consequence of an imbalance between $A \beta$ production and $A \beta$ clearance, suggesting

Table 2. Gene variants associated with Alzheimer disease

\begin{tabular}{|c|c|c|}
\hline Gene & Main alteration & Presumed mechanism \\
\hline Amyloid precursor protein $(A P P)$ & Mutation & Autosomal dominant, mostly early onset \\
\hline Presenilin 1 (PSEN1) & Mutation & Autosomal dominant, mostly early onset \\
\hline Presenilin 2 (PSEN2) & Mutation & Autosomal dominant, mostly early onset \\
\hline Apolipoprotein-E $(A P O E)$ & Common variant & Familial and sporadic, late onset \\
\hline $\begin{array}{l}\text { Sortilin-related receptor, } \mathrm{L}(\mathrm{DLR} \\
\text { class) A repeats-containing } \\
(S O R L 1)\end{array}$ & Common variant & Familial and sporadic, late onset \\
\hline Clusterin $(C L U)$ & Common variant & Sporadic, late onset \\
\hline $\begin{array}{l}\text { Phosphatidylinositol binding } \\
\text { clathrin assembly protein } \\
(\text { PICALM })\end{array}$ & Common variant & Sporadic, late onset \\
\hline $\begin{array}{l}\text { Complement component } \\
(3 \mathrm{~b} / 4 \mathrm{~b}) \text { receptor } 1(C R 1)\end{array}$ & Common variant & Sporadic, late onset \\
\hline Bridging integrator 1 (BIN1) & Common variant & Sporadic, late onset \\
\hline
\end{tabular}


that other genes involved in these pathways might also turn out to be risk factors.

\section{Common Variants}

The strongest common genetic variant for typical late-onset $\mathrm{AD}$ beginning after age approximately 65 years is apolipoprotein $\mathrm{E}(A P O E)$, a three-allele polymorphism $(\varepsilon 2, \varepsilon 3$, and $\varepsilon 4)$ where $\varepsilon 3$ is considered a neutral allele, $\varepsilon 4$ the high-risk allele, and $\varepsilon 2$ a protective allele (Table 2). The $\varepsilon 4$ allele influences age at onset in a dose-dependent manner (Corder et al. 1993). However, more than half of the patients with late-onset disease do not have the highrisk $\varepsilon 4$ allele. The population attributable risk related to APOE- $\varepsilon 4$ has been estimated at 20\% (Slooter et al. 1998). Genome-wide association (GWA) studies have identified variants in $C L U$, PICALM, CR1, and BIN1 as putative susceptibility loci (Harold et al. 2009; Lambert et al. 2009; Seshadri et al. 2010). These genetic variants have been confirmed in other nonHispanic and Hispanic populations (Carrasquillo et al. 2010; Jun et al. 2010; Lee et al. 2010). The odds ratios for these genes are much lower than for $A P O E(\mathrm{OR}=$ are 3.2 and 14.9 for $\varepsilon 3 / \varepsilon 4$ and $\varepsilon 4 / \varepsilon 4$, respectively [Farrer et al. 1997]) and range from 1.16 to 1.20 for CR1, CLU, and PICALM.

\section{Familial Late-Onset Alzheimer Disease}

Bertram et al. (2008) performed a GWA study in 1376 samples from 410 families with late-onset Alzheimer disease (LOAD) and subsequently replicated their findings. A locus on chromosome $14 \mathrm{q} 31$ was strongly associated with LOAD, but the identity of the underlying locus is unknown and may be a modifier of onset age. The results of GWA studies in the NIALOAD Family Study, involving $900+$ families stratified by APOE genotype, also identified single-nucleotide polymorphisms on chromosome 10p14 in CUGBP2 with genome wide significance within individuals with one $A P O E \& 4$ allele, which was replicated in an independent Caribbean Hispanic cohort (Wijsman et al. 2011). The NIA-LOAD Family Study also replicated the variants in BIN1 and provided modest confirmation for $C L U$, but not for CR1 or PICALM after APOE adjustment (Hollingworth et al. 2011; Naj et al. 2011). The role of these genes in the pathogenesis of Alzheimer's disease remains to be determined, but it is clear that large sample sizes have enabled identification of these putative gene variants.

Finally, variants in SORL1, which encodes a protein involved in trafficking of APP, are associated with late-onset $\mathrm{AD}$. Although in line with other recently described genetic links for AD (Lee et al. 2007; Rogaeva et al. 2007), the effect sizes of the SORL1 associations are modest (Reitz et al. 2011). Variants in the SORL1 homolog, SORCS1, are also modestly associated with $\mathrm{AD}$. Overexpression of either gene leads to a decrease in $A \beta$ levels in cultured cells, whereas inhibition by RNAi increases $A \beta$. Thus, both genes may play a role in $A D$ pathogenesis.

Although these results of the published GWA studies are informative, the genetic associations need functional validation. GWA studies represent a method of screening the genome, but limitations exist in their ability to detect true associations. The results of such studies might be difficult to replicate if the real effect turns out to be smaller than the effect observed in the initial study. In addition, GWA studies may not detect associations with multiple rare variants at a single site (which are better detected by linkage studies) or with single rare variants (minor allele frequency $<5 \%$ ). Finally, such studies alone cannot prove causality or establish the biological significance of an observed genetic association.

\section{CONCLUSIONS}

Our understanding of $\mathrm{AD}$ pathogenesis has grown substantially over the past two decades. However, with the large numbers of individuals reaching the age of highest risk, some would say that we have a long way to go toward preventing or limiting the full impact of the disease. Current treatments are palliative at best and newer therapies remain unproven. Knowing who is a risk and why will make prevention and 
management easier in the future (Aisen et al. 2011; Lee et al. 2011; Schenk et al. 2011).

\section{REFERENCES}

\section{* Reference is also in this collection.}

Aevarsson O, Skoog I. 1996. A population-based study on the incidence of dementia disorders between 85 and 88 years of age. J Am Geriatr Soc 44: 1455-1460.

* Aisen PS, Cummings JL, Schneider LS. 2011. Symptomatic and non-amyloid/Tau-based pharmacologic treatment for Alzheimer disease. Cold Spring Harb Perspect Med doi: 10.1101/cshperspect.a006395.

Akbaraly TN, Portet F, Fustinoni S, Dartigues JF, Artero S, Rouaud O, Touchon J, Ritchie K, Berr C. 2009. Leisure activities and the risk of dementia in the elderly: results from the Three-City Study. Neurology 73: 854-861.

Andersen K, Nielsen H, Lolk A, Andersen J, Becker I, KraghSorensen P. 1999. Incidence of very mild to severe dementia and Alzheimer's disease in Denmark: The Odense Study. Neurology 52: 85-90.

Angevaren M, Aufdemkampe G, Verhaar H, Aleman A, Vanhees L. 2008. Physical activity and enhanced fitness to improve cognitive function in older people without known cognitive impairment. Cochrane Database of Systematic Reviews (Online): CD005381.

Arbus C, Soto ME, Andrieu S, Nourhashemi F, Camus V, Schmitt L, Vellas B. 2008. The prevalence of clinically significant depressive symptoms in Alzheimer's disease: relationship with other psychological and behavioural symptoms. Int J Geriatr Psychiat 23: 1209-1211.

Athan ES, Williamson J, Ciappa A, Santana V, Romas SN, Lee JH, Rondon H, Lantigua RA, Medrano M, Torres $\mathrm{M}$, et al. 2001. A founder mutation in presenilin 1 causing early-onset Alzheimer disease in unrelated Caribbean Hispanic families. JAMA 286: 2257-2263.

Atti AR, Palmer K, Volpato S, Winblad B, De Ronchi D, Fratiglioni L. 2008. Late-life body mass index and dementia incidence: Nine-year follow-up data from the Kungsholmen Project. J Am Geriatr Soc 56: 111-116.

Bachman DL, Wolf PA, Linn RT, Knoefel JE, Cobb JL, Belanger AJ, White LR, D’Agostino RB. 1993. Incidence of dementia and probable Alzheimer's disease in a general population: The Framingham Study. Neurology 43: 515-519.

Bagger YZ, Tanko LB, Alexandersen P, Qin G, Christiansen C. 2004. The implications of body fat mass and fat distribution for cognitive function in elderly women. Obesity Res 12: 1519-1526.

Barba R, Martinez-Espinosa S, Rodriguez-Garcia E, Pondal M, Vivancos J, Del Ser T. 2000. Poststroke dementia: Clinical features and risk factors. Stroke 31: 1494-1501.

Barberger-Gateau P, Raffaitin C, Letenneur L, Berr C, Tzourio C, Dartigues JF, Alperovitch A. 2007. Dietary patterns and risk of dementia: The Three-City cohort study. Neurology 69: 1921-1930.

Bertram L, Lange C, Mullin K, Parkinson M, Hsiao M, Hogan MF, Schjeide BM, Hooli B, Divito J, Ionita I, et al. 2008. Genome-wide association analysis reveals putative Alzheimer's disease susceptibility loci in addition to APOE. Am J Hum Genet 83: 623-632.

Black JE, Isaacs KR, Anderson BJ, Alcantara AA, Greenough WT. 1990. Learning causes synaptogenesis, whereas motor activity causes angiogenesis, in cerebellar cortex of adult rats. Proc Natl Acad Sci 87: 5568-5572.

Blennow K, de Leon MJ, Zetterberg H. 2006. Alzheimer's disease. Lancet 368: 387-403.

Bohannon AD, Fillenbaum GG, Pieper CF, Hanlon JT, Blazer DG. 2002. Relationship of race/ethnicity and blood pressure to change in cognitive function. J Am Geriatr Soc 50: 424-429.

Borenstein AR, Wu Y, Mortimer JA, Schellenberg GD, McCormick WC, Bowen JD, McCurry S, Larson EB. 2005. Developmental and vascular risk factors for Alzheimer's disease. Neurobiol Aging 26: 325-334.

Brayne C, Gill C, Huppert FA, Barkley C, Gehlhaar E, Girling DM, O'Connor DW, Paykel ES. 1995. Incidence of clinically diagnosed subtypes of dementia in an elderly population. Cambridge Project for Later Life. Br J Psychiat 167: 255-262.

Brookmeyer R, Gray S, Kawas C. 1998. Projections of Alzheimer's disease in the United States and the public health impact of delaying disease onset. Am J Public Health 88: 1337-1342.

Brubacher D, Monsch AU, Stahelin HB. 2004. Weight change and cognitive performance. Int J Obes Relat Metab Disord 28: 1163-1167.

Buchman AS, Wilson RS, Bienias JL, Shah RC, Evans DA, Bennett DA. 2005. Change in body mass index and risk of incident Alzheimer disease. Neurology 65: 892-897.

Carrasquillo MM, Belbin O, Hunter TA, Ma L, Bisceglio GD, Zou F, Crook JE, Pankratz VS, Dickson DW, Graff-Radford NR, et al. 2010. Replication of CLU, CR1, and PICALM associations with Alzheimer disease. Arch Neurol 67: 961-964.

Carro E, Trejo JL, Busiguina S, Torres-Aleman I. 2001. Circulating insulin-like growth factor I mediates the protective effects of physical exercise against brain insults of different etiology and anatomy. $J$ Neurosci 21: $5678-5684$.

Chandra V, Pandav R, Dodge HH, Johnston JM, Belle SH, DeKosky ST, Ganguli M. 2001. Incidence of Alzheimer's disease in a rural community in India: The Indo-US study. Neurology 57: 985-989.

Chodosh J, Reuben DB, Albert MS, Seeman TE. 2002. Predicting cognitive impairment in high-functioning community-dwelling older persons: MacArthur Studies of Successful Aging. J Am Geriat Soc 50: 1051-1060.

Copeland JR, McCracken CF, Dewey ME, Wilson KC, Doran M, Gilmore C, Scott A, Larkin BA. 1999. Undifferentiated dementia, Alzheimer's disease and vascular dementia: age- and gender-related incidence in Liverpool. The MRC-ALPHA Study. Br J Psychiat 175: 433-438.

Corder EH, Saunders AM, Strittmatter WJ, Schmechel DE, Gaskell PC, Small GW, Roses AD, Haines JL, PericakVance MA. 1993. Gene dose of apolipoprotein E type 4 allele and the risk of Alzheimer's disease in late onset families. Science 261: 921-923. 
Cotman CW. Berchtold NC. 2002. Exercise: A behavioral intervention to enhance brain health and plasticity. Trends Neurosci 25: 295-301.

de Koning I, Dippel DW, van Kooten F, Koudstaal PJ. 2000. A short screening instrument for poststroke dementia: The R-CAMCOG. Stroke 31: 1502-1508.

de Koning I, van Kooten F, Koudstaal PJ, Dippel DW. 2005. Diagnostic value of the Rotterdam-CAMCOG in post-stroke dementia. J Neurol Neurosurg Psychiat 76: 263-265.

Desmond DW, Moroney JT, Paik MC, Sano M, Mohr JP, Aboumatar S, Tseng CL, Chan S, Williams JB, Remien $\mathrm{RH}$, et al. 2000. Frequency and clinical determinants of dementia after ischemic stroke. Neurology 54: $1124-1131$.

Desmond DW, Moroney JT, Sano M, Stern Y. 2002. Incidence of dementia after ischemic stroke: Results of a longitudinal study. Stroke 33: 2254-2260.

Di Carlo A, Baldereschi M, Amaducci L, Lepore V, Bracco L, Maggi S, Bonaiuto S, Perissinotto E, Scarlato G, Farchi G, et al. 2002. Incidence of dementia, Alzheimer's disease, and vascular dementia in Italy. The ILSA Study. $J$ Am Geriatr Soc 50: 41-48.

Doll R, Peto R, Boreham J, Sutherland I. 2000. Smoking and dementia in male British doctors: Prospective study. BMJ 320: 1097.

Edland SD, Rocca WA, Petersen RC, Cha RH, Kokmen E. 2002. Dementia and Alzheimer disease incidence rates do not vary by sex in Rochester, Minn. Arch Neurol 59: 1589-1593.

Elias MF, Elias PK, Sullivan LM, Wolf PA, D’Agostino RB. 2003. Lower cognitive function in the presence of obesity and hypertension: The Framingham heart study. Int $J$ Obes Relat Metab Disord 27: 260-268.

Elias PK, Elias MF, Robbins MA, Budge MM. 2004. Blood pressure-related cognitive decline: Does age make a difference? Hypertension 44: 631-636.

Emmerling MR, Morganti-Kossmann MC, Kossmann T, Stahel PF, Watson MD, Evans LM, Mehta PD, Spiegel $\mathrm{K}$, Kuo YM, Roher AE, et al. 2000. Traumatic brain injury elevates the Alzheimer's amyloid peptide $A \beta 42$ in human CSF. A possible role for nerve cell injury. Ann NYAcad Sci 903: $118-122$.

Engelhart MJ, Geerlings MI, Ruitenberg A, van Swieten JC, Hofman A, Witteman JC, Breteler MM. 2002. Dietary intake of antioxidants and risk of Alzheimer disease. JAMA 287: 3223-3229.

Evans DA, Funkenstein HH, Albert MS, Scherr PA, Cook NR, Chown MJ, Hebert LE, Hennekens CH, Taylor JO. 1989. Prevalence of Alzheimer's disease in a community population of older persons. Higher than previously reported. JAMA 262: 2551-2556.

Evans DA, Beckett LA, Albert MS, Hebert LE, Scherr PA, Funkenstein HH, Taylor JO. 1993. Level of education and change in cognitive function in a community population of older persons. Ann Epidemiol 3: 71-77.

Evans DA, Hebert LE, Beckett LA, Scherr PA, Albert MS, Chown MJ, Pilgrim DM, Taylor JO. 1997. Education and other measures of socioeconomic status and risk of incident Alzheimer disease in a defined population of older persons. Arch Neurol 54: 1399-1405.
Farrer LA, Cupples LA, Haines JL, Hyman B, Kukull WA, Mayeux R, Myers RH, Pericak-Vance MA, Risch N, van Duijn CM. 1997. Effects of age, sex, and ethnicity on the association between apolipoprotein E genotype and Alzheimer disease. A meta-analysis. APOE and Alzheimer Disease Meta Analysis Consortium. JAMA 278: 1349-1356.

Farris W, Mansourian S, Chang Y, Lindsley L, Eckman EA, Frosch MP, Eckman CB, Tanzi RE, Selkoe DJ, Guenette S. 2003. Insulin-degrading enzyme regulates the levels of insulin, amyloid $\beta$-protein, and the $\beta$-amyloid precursor protein intracellular domain in vivo. Proc Natl Acad Sci 100: $4162-4167$.

Faxen-Irving G, Basun H, Cederholm T. 2005. Nutritional and cognitive relationships and long-term mortality in patients with various dementia disorders. Age Ageing 34: 136-141.

Fein G, Di Sclafani V, Tanabe J, Cardenas V, Weiner MW, Jagust WJ, Reed BR, Norman D, Schuff N, Kusdra L, et al. 2000. Hippocampal and cortical atrophy predict dementia in subcortical ischemic vascular disease. Neurology 55: $1626-1635$.

Ferri CP, Prince M, Brayne C, Brodaty H, Fratiglioni L, Ganguli M, Hall K, Hasegawa K, Hendrie H, Huang Y, et al. 2005. Global prevalence of dementia: A Delphi consensus study. Lancet 366: 2112-2117.

Fitzpatrick AL, Kuller LH, Ives DG, Lopez OL, Jagust W, Breitner JC, Jones B, Lyketsos C, Dulberg C. 2004. Incidence and prevalence of dementia in the Cardiovascular Health Study. J Am Geriatr Soc 52: 195-204.

Fleminger S, Oliver DL, Lovestone S, Rabe-Hesketh S, Giora A. 2003. Head injury as a risk factor for Alzheimer's disease: The evidence 10 years on; a partial replication. J Neurol Neurosurg Psychiat 74: 857-862.

Ford ES. 2002. Does exercise reduce inflammation? Physical activity and C-reactive protein among U.S. adults. Epidemiology 13: 561-568.

Forette F, Seux ML, Staessen JA, Thijs L, Babarskiene MR, Babeanu S, Bossini A, Fagard R, Gil-Extremera B, Laks T, et al. 2002. The prevention of dementia with antihypertensive treatment: New evidence from the Systolic Hypertension in Europe (Syst-Eur) study. Arch Intern Med 162: 2046-2052.

Franz G, Beer R, Kampfl A, Engelhardt K, Schmutzhard E, Ulmer H, Deisenhammer F. 2003. Amyloid $\beta$ 1-42 and tau in cerebrospinal fluid after severe traumatic brain injury. Neurology 60: 1457-1461.

Fratiglioni L, Viitanen M, von Strauss E, Tontodonati V, Herlitz A, Winblad B. 1997. Very old women at highest risk of dementia and Alzheimer's disease: Incidence data from the Kungsholmen Project, Stockholm. Neurology 48: 132-138.

Fratiglioni L, Paillard-Borg S, Winblad B. 2004. An active and socially integrated lifestyle in late life might protect against dementia. Lancet Neurol 3: 343-353.

Galasko D, Hansen LA, Katzman R, Wiederholt W, Masliah E, Terry R, Hill LR, Lessin P, Thal LJ. 1994. Clinical-neuropathological correlations in Alzheimer's disease and related dementias. Arch Neurol 51: 888-895.

Gamaldo A, Moghekar A, Kilada S, Resnick SM, Zonderman AB, O’Brien R. 2006. Effect of a clinical stroke on 
the risk of dementia in a prospective cohort. Neurology 67: $1363-1369$.

Ganguli M, Dodge HH, Chen P, Belle S, DeKosky ST. 2000. Ten-year incidence of dementia in a rural elderly US community population: The MoVIES Project. Neurology 54: 1109-1116.

Geerlings MI, Deeg DJ, Penninx BW, Schmand B, Jonker C, Bouter LM, van Tilburg W. 1999. Cognitive reserve and mortality in dementia: The role of cognition, functional ability and depression. Psychol Med 29: 1219-1226.

Goate A, Chartier-Harlin MC, Mullan M, Brown J, Crawford F, Fidani L, Giuffra L, Haynes A, Irving N, James L, et al. 1991. Segregation of a missense mutation in the amyloid precursor protein gene with familial Alzheimer's disease. Nature 349: 704-706.

Goble AJ. 2005. Obesity in middle age and future risk of dementia: Problem is probably greater for women. BMJ 331: 454.

Gustafson D, Rothenberg E, Blennow K, Steen B, Skoog I. 2003. An 18-year follow-up of overweight and risk of Alzheimer disease. Arch Intern Med 163: 1524-1528.

Hall KS, Gao S, Unverzagt FW, Hendrie HC. 2000. Low education and childhood rural residence: Risk for Alzheimer's disease in African Americans. Neurology 54: 95-99.

Harold D, Abraham R, Hollingworth P, Sims R, Gerrish A, Hamshere ML, Pahwa JS, Moskvina V, Dowzell K, Williams A, et al. 2009. Genome-wide association study identifies variants at CLU and PICALM associated with Alzheimer's disease. Nat Genet 41: 1088-1093.

Hartman RE, Laurer H, Longhi L, Bales KR, Paul SM, McIntosh TK, Holtzman DM. 2002. Apolipoprotein E4 influences amyloid deposition but not cell loss after traumatic brain injury in a mouse model of Alzheimer's disease. J Neurosci 22: 10083-10087.

Hebert LE, Scherr PA, Beckett LA, Albert MS, Pilgrim DM, Chown MJ, Funkenstein HH, Evans DA. 1995. Age-specific incidence of Alzheimer's disease in a community population. JAMA 273: 1354-1359.

Hebert LE, Scherr PA, Bennett DA, Bienias JL, Wilson RS, Morris MC, Evans DA. 2004. Blood pressure and late-life cognitive function change: A biracial longitudinal population study. Neurology 62: 2021-2024.

Helzner EP, Scarmeas N, Cosentino S, Portet F, Stern Y. 2007. Leisure activity and cognitive decline in incident Alzheimer disease. Arch Neurol 64: 1749-1754.

Hendrie HC, Ogunniyi A, Hall KS, Baiyewu O, Unverzagt FW, Gureje O, Gao S, Evans RM, Ogunseyinde AO, Adeyinka AO, et al. 2001. Incidence of dementia and Alzheimer disease in 2 communities: Yoruba residing in Ibadan, Nigeria, and African Americans residing in Indianapolis, Indiana. JAMA 285: 739-747.

Henon H, Durieu I, Guerouaou D, Lebert F, Pasquier F, Leys D. 2001. Poststroke dementia: Incidence and relationship to prestroke cognitive decline. Neurology 57: 1216-1222.

Hollingworth P, Harold D, Sims R, Gerrish A, Lambert JC, Carrasquillo MM, Abraham R, Hamshere ML, Pahwa JS, Moskvina V, et al. 2011. Common variants at ABCA7, MS4A6A/MS4A4E, EPHA1, CD33 and CD2AP are associated with Alzheimer's disease. Nat Genet 43: $429-435$.
Honig LS, Tang MX, Albert S, Costa R, Luchsinger J, Manly J, Stern Y, Mayeux R. 2003. Stroke and the risk of Alzheimer disease. Arch Neurol 60: 1707-1712.

Ivan CS, Seshadri S, Beiser A, Au R, Kase CS, Kelly-Hayes M, Wolf PA. 2004. Dementia after stroke: The Framingham Study. Stroke 35: 1264-1268.

Iwata A, Chen XH, McIntosh TK, Browne KD, Smith DH. 2002. Long-term accumulation of amyloid- $\beta$ in axons following brain trauma without persistent upregulation of amyloid precursor protein genes. J Neuropathol Exp Neurol 61: 1056-1068.

Jellinger KA. 2002. The pathology of ischemic-vascular dementia: An update. J Neurol Sci 203-204: 153-157.

Jellinger KA, Attems J. 2010. Prevalence of dementia disorders in the oldest-old: An autopsy study. Acta Neuropathol 119: 421-433.

Jeong SK, Nam HS, Son MH, Son EJ, Cho KH. 2005. Interactive effect of obesity indexes on cognition. Dement Geriatr Cogn Disord 19: 91-96.

Jin YP, Di Legge S, Ostbye T, Feightner JW, Hachinski V. 2006. The reciprocal risks of stroke and cognitive impairment in an elderly population. Alzheimer's Dement 2: $171-178$.

Jin YP, Ostbye T, Feightner JW, Di Legge S, Hachinski V. 2008. Joint effect of stroke and APOE 4 on dementia risk: The Canadian Study of Health and Aging. Neurology 70: 9-16.

Jun G, Naj AC, Beecham GW, Wang LS, Buros J, Gallins PJ, Buxbaum JD, Ertekin-Taner N, Fallin MD, Friedland R, et al. 2010. Meta-analysis confirms CR1, CLU, and PICALM as Alzheimer disease risk loci and reveals interactions with APOE genotypes. Arch Neurol 67: 1473-1484.

Kawas C, Gray S, Brookmeyer R, Fozard J, Zonderman A. 2000. Age-specific incidence rates of Alzheimer's disease: The Baltimore Longitudinal Study of Aging. Neurology 54: $2072-2077$.

Kilander L, Nyman H, Boberg M, Lithell H. 2000. The association between low diastolic blood pressure in middle age and cognitive function in old age. A populationbased study. Age Ageing 29: 243-248.

Kivipelto M, Ngandu T, Fratiglioni L, Viitanen M, Kareholt I, Winblad B, Helkala EL, Tuomilehto J, Soininen H, Nissinen A. 2005. Obesity and vascular risk factors at midlife and the risk of dementia and Alzheimer disease. Arch Neurol 62: 1556-1560.

Klimkowicz A, Dziedzic T, Slowik A, Szczudlik A. 2002. Incidence of pre- and poststroke dementia: Cracow Stroke Registry. Dement Geriatr Cogn Disord 14: 137-140.

Knopman D, Boland LL, Mosley T, Howard G, Liao D, Szklo M, McGovern P, Folsom AR. 2001. Cardiovascular risk factors and cognitive decline in middle-aged adults. Neurology 56: 42-48.

Knopman DS, Rocca WA, Cha RH, Edland SD, Kokmen E. 2002. Incidence of vascular dementia in Rochester, Minn, 1985-1989. Arch Neurol 59: 1605-1610.

Koponen S, Taiminen T, Kairisto V, Portin R, Isoniemi H, Hinkka S, Tenovuo O. 2004. APOE- $\varepsilon 4$ predicts dementia but not other psychiatric disorders after traumatic brain injury. Neurology 63: 749-750.

Kukull WA, Higdon R, Bowen JD, McCormick WC, Teri L, Schellenberg GD, van Belle G, Jolley L, Larson EB. 
2002. Dementia and Alzheimer disease incidence: A prospective cohort study. Arch Neurol 59: 1737-1746.

Kuller LH, Lopez OL, Newman A, Beauchamp NJ, Burke G, Dulberg C, Fitzpatrick A, Fried L, Haan MN. 2003. Risk factors for dementia in the cardiovascular health cognition study. Neuroepidemiology 22: 13-22.

Kuller LH, Lopez OL, Jagust WJ, Becker JT, DeKosky ST, Lyketsos C, Kawas C, Breitner JC, Fitzpatrick A, Dulberg C. 2005. Determinants of vascular dementia in the Cardiovascular Health Cognition Study. Neurology 64: $1548-1552$.

Lambert JC, Heath S, Even G, Campion D, Sleegers K, Hiltunen M, Combarros O, Zelenika D, Bullido MJ, Tavernier B, et al. 2009. Genome-wide association study identifies variants at CLU and CR1 associated with Alzheimer's disease. Nat Genet 41: 1094-1099.

Larson EB, Wang L, Bowen JD, McCormick WC, Teri L, Crane P, Kukull W. 2006. Exercise is associated with reduced risk for incident dementia among persons 65 years of age and older. Ann Intern Med 144: 73-81.

Launer LJ, Andersen K, Dewey ME, Letenneur L, Ott A, Amaducci LA, Brayne C, Copeland JR, Dartigues JF, Kragh-Sorensen P, et al. 1999. Rates and risk factors for dementia and Alzheimer's disease: results from EURODEM pooled analyses. EURODEM Incidence Research Group and Work Groups. European Studies of Dementia. Neurology 52: 78-84.

Launer LJ, Ross GW, Petrovitch H, Masaki K, Foley D, White LR, Havlik RJ. 2000. Midlife blood pressure and dementia: The Honolulu-Asia aging study. Neurobiol Aging 21: 49-55.

Lee JH, Cheng R, Schupf N, Manly J, Lantigua R, Stern Y, Rogaeva E, Wakutani Y, Farrer L, St George-Hyslop P, et al. 2007. The association between genetic variants in SORL1 and Alzheimer disease in an urban, multiethnic, community-based cohort. Arch Neurol 64: 501-506.

Lee JH, Cheng R, Barral S, Reitz C, Medrano M, Lantigua R, Jimenez-Velazquez IZ, Rogaeva E, St George-Hyslop PH, Mayeux R. 2010. Identification of novel loci for Alzheimer disease and replication of CLU, PICALM, and BIN1 in Caribbean Hispanic individuals. Arch Neurol 68: $320-328$

* Lee V, Brunden KR, Hutton M, Trojanowski JQ. 2011. Developing therapeutic approaches to Tau, selected kinases, and related neuronal protein targets. Cold Spring Harb Perspect Med doi: 10.1101/cshperspect.a006437.

Letenneur L, Commenges D, Dartigues JF, BarbergerGateau P. 1994. Incidence of dementia and Alzheimer's disease in elderly community residents of south-western France. Int J Epidemiol 23: 1256-1261.

Letenneur L, Gilleron V, Commenges D, Helmer C, Orgogozo JM, Dartigues JF. 1999. Are sex and educational level independent predictors of dementia and Alzheimer's disease? Incidence data from the PAQUID project. J Neurol Neurosurg Psychiat 66: 177-183.

Levy-Lahad E, Wasco W, Poorkaj P, Romano DM, Oshima J, Pettingell WH, Yu CE, Jondro PD, Schmidt SD, Wang K, et al. 1995a. Candidate gene for the chromosome 1 familial Alzheimer's disease locus. Science 269: 973-977.

Levy-Lahad E, Wijsman EM, Nemens E, Anderson L, Goddard KA, Weber JL, Bird TD, Schellenberg GD. 1995b. A familial Alzheimer's disease locus on chromosome 1. Science 269: 970-973.

Liebetrau M, Steen B, Skoog I. 2003. Stroke in 85-year-olds: Prevalence, incidence, risk factors, and relation to mortality and dementia. Stroke 34: 2617-2622.

Lim A, Tsuang D, Kukull W, Nochlin D, Leverenz J, McCormick W, Bowen J, Teri L, Thompson J, Peskind ER, et al. 1999. Clinico-neuropathological correlation of Alzheimer's disease in a community-based case series. J Am Geriatr Soc 47: 564-569.

Linden T, Skoog I, Fagerberg B, Steen B, Blomstrand C. 2004. Cognitive impairment and dementia 20 months after stroke. Neuroepidemiology 23: 45-52.

Lindsay J, Laurin D, Verreault R, Hebert R, Helliwell B, Hill GB, McDowell I. 2002. Risk factors for Alzheimer's disease: A prospective analysis from the Canadian Study of Health and Aging. Am J Epidemiol 156: 445-453.

Lithell H, Hansson L, Skoog I, Elmfeldt D, Hofman A, Olofsson B, Trenkwalder P, Zanchetti A. 2003. The Study on Cognition and Prognosis in the Elderly (SCOPE): Principal results of a randomized double-blind intervention trial. J Hypertens 21: 875-886.

Lobo A, Launer LJ, Fratiglioni L, Andersen K, Di Carlo A, Breteler MM, Copeland JR, Dartigues JF, Jagger C, Martinez-Lage J, et al. 2000. Prevalence of dementia and major subtypes in Europe: A collaborative study of population-based cohorts. Neurologic Diseases in the Elderly Research Group. Neurology 54: S4-S9.

Lopez-Pousa S, Vilalta-Franch J, Llinas-Regla J, Garre-Olmo J, Roman GC. 2004. Incidence of dementia in a rural community in Spain: The Girona cohort study. Neuroepidemiology 23: 170-177.

Luchsinger JA, Tang MX, Stern Y, Shea S, Mayeux R. 2001. Diabetes mellitus and risk of Alzheimer's disease and dementia with stroke in a multiethnic cohort. Am J Epidemiol 154: 635-641.

Luchsinger JA, Tang MX, Shea S, Mayeux R. 2002. Caloric intake and the risk of Alzheimer disease. Arch Neurol 59: $1258-1263$.

Luchsinger JA, Tang MX, Shea S, Mayeux R. 2003. Antioxidant vitamin intake and risk of Alzheimer disease. Arch Neurol 60: 203-208.

Luchsinger JA, Tang MX, Shea S, Mayeux R. 2004a. Hyperinsulinemia and risk of Alzheimer disease. Neurology 63: 1187-1192.

Luchsinger JA, Tang MX, Shea S, Miller J, Green R, Mayeux R. 2004b. Plasma homocysteine levels and risk of Alzheimer disease. Neurology 62: 1972-1976.

Luchsinger JA, Tang MX, Miller J, Green R, Mayeux R. 2007. Relation of higher folate intake to lower risk of Alzheimer disease in the elderly. Arch Neurol 64: 86-92.

Manly JJ, Schupf N, Tang MX, Stern Y. 2005. Cognitive decline and literacy among ethnically diverse elders. J Geriat Psychiat Neurol 18: 213-217.

McKhann G, Drachman D, Folstein M, Katzman R, Price D, Stadlan EM. 1984. Clinical diagnosis of Alzheimer's disease: Report of the NINCDS-ADRDA Work Group under the auspices of Department of Health and Human Services Task Force on Alzheimer's Disease. Neurology 34: 939-944. 
McKhann GM, Knopman DS, Chertkow H, Hyman BT, Jack CR Jr, Kawas CH, Klunk WE, Koroshetz WJ, Manly JJ, Mayeux R, et al. 2011. The diagnosis of dementia due to Alzheimer's disease: Recommendations from the National Institute on Aging-Alzheimer's Association workgroups on diagnostic guidelines for Alzheimer's disease. Alzheimers Dement 7: 263-269.

Morris MC, Scherr PA, Hebert LE, Glynn RJ, Bennett DA, Evans DA. 2001. Association of incident Alzheimer disease and blood pressure measured from 13 years before to 2 years after diagnosis in a large community study. Arch Neurol 58: 1640-1646.

Morris MC, Evans DA, Bienias JL, Tangney CC, Bennett DA, Aggarwal N, Wilson RS, Scherr PA. 2002. Dietary intake of antioxidant nutrients and the risk of incident Alzheimer disease in a biracial community study. JAMA 287: $3230-3237$.

Morris MC, Evans DA, Bienias JL, Tangney CC, Bennett DA, Aggarwal N, Schneider J, Wilson RS. 2003. Dietary fats and the risk of incident Alzheimer disease. Arch Neurol 60: $194-200$.

Morris MC, Evans DA, Schneider JA, Tangney CC, Bienias JL, Aggarwal NT. 2006. Dietary folate and vitamins B-12 and B-6 not associated with incident Alzheimer's disease. J Alzheimer's Dis 9: 435-443.

Naj AC, Jun G, Beecham GW, Wang LS, Vardarajan BN, Buros J, Gallins PJ, Buxbaum JD, Jarvik GP, Crane PK, et al. 2011. Common variants at MS4A4/MS4A6E, CD2AP, CD33 and EPHA1 are associated with late-onset Alzheimer's disease. Nat Genet 43: 436-441.

Nitrini R, Caramelli P, Herrera E Jr, Bahia VS, Caixeta LF, Radanovic M, Anghinah R, Charchat-Fichman H, Porto CS, Carthery MT, et al. 2004. Incidence of dementia in a community-dwelling Brazilian population. Alzheimer Dis Assoc Disord 18: 241-246.

Nourhashemi F, Andrieu S, Gillette-Guyonnet S, Reynish E, Albarede JL, Grandjean H, Vellas B. 2002. Is there a relationship between fat-free soft tissue mass and low cognitive function? Results from a study of 7,105 women. J Am Geriatr Soc 50: 1796-1801.

Nourhashemi F, Deschamps V, Larrieu S, Letenneur L, Dartigues JF, Barberger-Gateau P. 2003. Body mass index and incidence of dementia: The PAQUID study. Neurology 60: 117-119.

Ogunniyi A, Baiyewu O, Gureje O, Hall KS, Unverzagt F, Siu SH, Gao S, Farlow M, Oluwole OS, Komolafe O, et al. 2000. Epidemiology of dementia in Nigeria: Results from the Indianapolis-Ibadan study. Eur J Neurol 7: 485-490.

Peila R, Rodriguez BL, Launer LJ. 2002. Type 2 diabetes, APOE gene, and the risk for dementia and related pathologies: The Honolulu-Asia Aging Study. Diabetes 51: $1256-1262$.

Pendlebury ST, Rothwell PM. 2009. Prevalence, incidence, and factors associated with pre-stroke and post-stroke dementia: A systematic review and meta-analysis. Lancet Neurol 8: 1006-1018.

Perry G, Cash AD, Smith MA. 2002. Alzheimer disease and oxidative stress. J Biomed Biotechnol 2: 120-123.

Peters R, Pinto E, Beckett N, Swift C, Potter J, McCormack T, Nunes M, Grimley-Evans J, Fletcher A, Bulpitt C. 2010. Association of depression with subsequent mortality, cardiovascular morbidity and incident dementia in people aged 80 and over and suffering from hypertension. Data from the Hypertension in the Very Elderly Trial (HYVET). Age Ageing 39: 439-445.

Petitti DB, Crooks VC, Buckwalter JG, Chiu V. 2005. Blood pressure levels before dementia. Arch Neurol 62: $112-116$.

Piguet O, Grayson DA, Creasey H, Bennett HP, Brooks WS, Waite LM, Broe GA. 2003. Vascular risk factors, cognition and dementia incidence over 6 years in the Sydney Older Persons Study. Neuroepidemiology 22: 165-171.

Podewils LJ, Guallar E, Kuller LH, Fried LP, Lopez OL, Carlson M, Lyketsos CG. 2005. Physical activity, APOE genotype, and dementia risk: Findings from the Cardiovascular Health Cognition Study. Am J Epidemiol 161: 639-651.

Posner HB, Tang MX, Luchsinger J, Lantigua R, Stern Y, Mayeux R. 2002. The relationship of hypertension in the elderly to $\mathrm{AD}$, vascular dementia, and cognitive function. Neurology 58: 1175-1181.

Profenno LA, Porsteinsson AP, Faraone SV. 2009. Metaanalysis of Alzheimer's disease risk with obesity, diabetes, and related disorders. Biol Psychiat 67: 505-512.

Qiu C, Backman L, Winblad B, Aguero-Torres H, Fratiglioni L. 2001. The influence of education on clinically diagnosed dementia incidence and mortality data from the Kungsholmen Project. Arch Neurol 58: 2034-2039.

Qiu C, von Strauss E, Fastbom J, Winblad B, Fratiglioni L. 2003. Low blood pressure and risk of dementia in the Kungsholmen project: A 6-year follow-up study. Arch Neurol 60: 223-228.

Rastas S, Pirttila T, Mattila K, Verkkoniemi A, Juva K, Niinisto L, Lansimies E, Sulkava R. 2010. Vascular risk factors and dementia in the general population aged $>85$ years: Prospective population-based study. Neurobiol Aging 31: 1-7.

Ravaglia G, Forti P, Maioli F, Martelli M, Servadei L, Brunetti N, Dalmonte E, Bianchin M, Mariani E. 2005a. Incidence and etiology of dementia in a large elderly Italian population. Neurology 64: 1525-1530.

Ravaglia G, Forti P, Maioli F, Martelli M, Servadei L, Brunetti N, Porcellini E, Licastro F. 2005b. Homocysteine and folate as risk factors for dementia and Alzheimer disease. Am J Clin Nutr 82: 636-643.

Razay G, Vreugdenhil A. 2005. Obesity in middle age and future risk of dementia: midlife obesity increases risk of future dementia. BMJ 331.

Reger MA, Watson GS, Green PS, Wilkinson CW, Baker LD, Cholerton B, Fishel MA, Plymate SR, Breitner JC, DeGroodt $\mathrm{W}$, et al. 2008. Intranasal insulin improves cognition and modulates $\beta$-amyloid in early AD. Neurology 70: $440-448$.

Reinprecht F, Elmstahl S, Janzon L, Andre-Petersson L. 2003. Hypertension and changes of cognitive function in 81-year-old men: a 13-year follow-up of the population study "Men born in 1914," Sweden. J Hypertens 21: $57-66$.

Reitz C, Bos MJ, Hofman A, Koudstaal PJ, Breteler MM. 2008. Prestroke cognitive performance, incident stroke, and risk of dementia: The Rotterdam Study. Stroke 39: 36-41. 
Reitz C, Tang MX, Miller J, Green R, Luchsinger JA. 2009. Plasma homocysteine and risk of mild cognitive impairment. Dement Geriatr Cogn Disord 27: 11-17.

Reitz C, Cheng R, Rogaeva E, Lee JH, Tokuhiro S, Zou F, Bettens K, Sleegers K, Tan EK, Kimura R, et al. 2011. Metaanalysis of the association between variants in SORL1 and Alzheimer disease. Arch Neurol 68: 99-106.

Reuben DB, Judd-Hamilton L, Harris TB, Seeman TE. 2003. The associations between physical activity and inflammatory markers in high-functioning older persons: MacArthur Studies of Successful Aging. J Am Geriatr Soc 51: $1125-1130$.

Risner ME, Saunders AM, Altman JF, Ormandy GC, Craft S, Foley IM, Zvartau-Hind ME, Hosford DA, Roses AD. 2006. Efficacy of rosiglitazone in a genetically defined population with mild-to-moderate Alzheimer's disease. Pharmacogenom J 6: 246-254.

Rogaev EI, Sherrington R, Rogaeva EA, Levesque G, Ikeda M, Liang Y, Chi H, Lin C, Holman K, Tsuda T, et al. 1995. Familial Alzheimer's disease in kindreds with missense mutations in a gene on chromosome 1 related to the Alzheimer's disease type 3 gene. Nature 376: 775-778.

Rogaeva E, Meng Y, Lee JH, Gu Y, Kawarai T, Zou F, Katayama T, Baldwin CT, Cheng R, Hasegawa H, et al. 2007. The neuronal sortilin-related receptor SORL1 is genetically associated with Alzheimer disease. Nat Genet 39: $168-177$.

Rosengren A, Skoog I, Gustafson D, Wilhelmsen L. 2005. Body mass index, other cardiovascular risk factors, and hospitalization for dementia. Arch Intern Med 165: 321-326.

Rottkamp CA, Nunomura A, Raina AK, Sayre LM, Perry G, Smith MA. 2000. Oxidative stress, antioxidants, and Alzheimer disease. Alzheimer Dis Assoc Disord 14 (Suppl 1): S62-S66.

Rovio S, Kareholt I, Helkala EL, Viitanen M, Winblad B, Tuomilehto J, Soininen H, Nissinen A, Kivipelto M. 2005. Leisure-time physical activity at midlife and the risk of dementia and Alzheimer's disease. Lancet Neurol 4: 705-711.

Ruitenberg A, Skoog I, Ott A, Aevarsson O, Witteman JC, Lernfelt B, van Harskamp F, Hofman A, Breteler MM. 2001. Blood pressure and risk of dementia: results from the Rotterdam study and the Gothenburg H-70 Study. Dement Geriatr Cogn Disord 12: 33-39.

Sato T, Hanyu H, Hirao K, Kanetaka H, Sakurai H, Iwamoto T. 2009. Efficacy of PPAR- $\gamma$ agonist pioglitazone in mild Alzheimer disease. Neurobiol Aging 32: 1626-1633.

Scarmeas N, Levy G, Tang MX, Manly J, Stern Y. 2001. Influence of leisure activity on the incidence of Alzheimer's disease. Neurology 57: 2236-2242.

Scarmeas N, Albert SM, Manly JJ, Stern Y. 2006a. Education and rates of cognitive decline in incident Alzheimer's disease. J Neurol Neurosurg Psychiat 77: 308-316.

Scarmeas N, Stern Y, Mayeux R, Luchsinger JA. 2006b. Mediterranean diet, Alzheimer disease, and vascular mediation. Arch Neurol 63: 1709-1717.

Scarmeas N, Luchsinger JA, Schupf N, Brickman AM, Cosentino S, Tang MX, Stern Y. 2009. Physical activity, diet, and risk of Alzheimer disease. JAMA 302: 627-637.
Schaefer EJ, Bongard V, Beiser AS, Lamon-Fava S, Robins SJ, Au R, Tucker KL, Kyle DJ, Wilson PW, Wolf PA. 2006. Plasma phosphatidylcholine docosahexaenoic acid content and risk of dementia and Alzheimer disease: The Framingham Heart Study. Arch Neurol 63: 1545-1550.

* Schenk D, Basi GS, Pangalos MN. 2011. Treatment strategies targeting amyloid-protein. Cold Spring Harb Perspect Med doi: 10.1101/cshperspect.a006387.

Schneider JA, Bennett DA. 2010. Where vascular meets neurodegenerative disease. Stroke 41: S144-S146.

Selkoe DJ. 2000. The origins of Alzheimer disease: A is for amyloid. JAMA 283: 1615-1617.

* Serrano-Pozo A, Frosch MP, Masliah E, Hyman BT. 2011. Neuropathological alterations in Alzheimer disease. Cold Spring Harb Perspect Med doi: 10.1101/cshperspect. a006189.

Seshadri S. 2006. Elevated plasma homocysteine levels: Risk factor or risk marker for the development of dementia and Alzheimer's disease? J Alzheimer's Dis 9: 393-398.

Seshadri S, Fitzpatrick AL, Ikram MA, DeStefano AL, Gudnason V, Boada M, Bis JC, Smith AV, Carassquillo MM, Lambert JC, et al. 2010. Genome-wide analysis of genetic loci associated with Alzheimer disease. JAMA 303: $1832-1840$.

Sherrington R, Rogaev EI, Liang Y, Rogaeva EA, Levesque G, Ikeda M, Chi H, Lin C, Li G, Holman K, et al. 1995. Cloning of a gene bearing missense mutations in early-onset familial Alzheimer's disease. Nature 375: 754-760.

Sherrington R, Froelich S, Sorbi S, Campion D, Chi H, Rogaeva EA, Levesque G, Rogaev EI, Lin C, Liang Y, et al. 1996. Alzheimer's disease associated with mutations in presenilin 2 is rare and variably penetrant. Human $\mathrm{Mol}$ Genet 5: 985-988.

Simons LA, Simons J, McCallum J, Friedlander Y. 2006. Lifestyle factors and risk of dementia: Dubbo Study of the elderly. Med J Australia 184: 68-70.

Skoog I, Lernfelt B, Landahl S, Palmertz B, Andreasson LA, Nilsson L, Persson G, Oden A, Svanborg A. 1996. 15-Year longitudinal study of blood pressure and dementia. Lancet 347: 1141-1145.

Slooter AJ, Cruts M, Kalmijn S, Hofman A, Breteler MM, Van Broeckhoven C, van Duijn CM. 1998. Risk estimates of dementia by apolipoprotein $\mathrm{E}$ genotypes from a population-based incidence study: The Rotterdam Study. Arch Neurol 55: 964-968.

Smith C, Graham DI, Murray LS, Nicoll JA. 2003. Tau immunohistochemistry in acute brain injury. Neuropathol Appl Neurobiol 29: 496-502.

Solfrizzi V, Panza F, Colacicco AM, D’Introno A, Capurso C, Torres F, Grigoletto F, Maggi S, Del Parigi A, Reiman EM, et al. 2004. Vascular risk factors, incidence of MCI, and rates of progression to dementia. Neurology 63: $1882-1891$.

Sparks DL, Kuo YM, Roher A, Martin T, Lukas RJ. 2000. Alterations of Alzheimer's disease in the cholesterol-fed rabbit, including vascular inflammation. Preliminary observations. Ann NY Acad Sci 903: 335-344.

Srikanth VK, Anderson JF, Donnan GA, Saling MM, Didus E, Alpitsis R, Dewey HM, Macdonell RA, Thrift AG. 2004. Progressive dementia after first-ever stroke: A 
community-based follow-up study. Neurology 63: $785-792$.

Srikanth VK, Quinn SJ, Donnan GA, Saling MM, Thrift AG. 2006. Long-term cognitive transitions, rates of cognitive change, and predictors of incident dementia in a population-based first-ever stroke cohort. Stroke 37: 2479-2483.

Stern Y, Gurland B, Tatemichi TK, Tang MX, Wilder D, Mayeux R. 1994. Influence of education and occupation on the incidence of Alzheimer's disease. JAMA 271: 1004-1010.

Stern Y, Albert S, Tang MX, Tsai WY. 1999. Rate of memory decline in $\mathrm{AD}$ is related to education and occupation: Cognitive reserve? Neurology 53: 1942-1957.

Stewart R, Masaki K, Xue QL, Peila R, Petrovitch H, White LR, Launer LJ. 2005. A 32-year prospective study of change in body weight and incident dementia: The Honolulu-Asia Aging Study. Arch Neurol 62: 55-60.

Stone JR, Okonkwo DO, Singleton RH, Mutlu LK, Helm GA, Povlishock JT. 2002. Caspase-3-mediated cleavage of amyloid precursor protein and formation of amyloid Beta peptide in traumatic axonal injury. J Neurotrauma 19: $601-614$.

Swartz RH, Stuss DT, Gao F, Black SE. 2008. Independent cognitive effects of atrophy and diffuse subcortical and thalamico-cortical cerebrovascular disease in dementia. Stroke 39: 822-830.

Tabet N. 2005. Obesity in middle age and future risk of dementia: Dietary fat and sugar may hold the clue. BMJ 331: 454-455.

Tang MX, Cross P, Andrews H, Jacobs DM, Small S, Bell K, Merchant C, Lantigua R, Costa R, Stern Y, et al. 2001. Incidence of AD in African-Americans, Caribbean Hispanics, and Caucasians in northern Manhattan. Neurology 56: 49-56.

Tang WK, Chan SS, Chiu HF, Ungvari GS, Wong KS, Kwok TC, Mok V, Wong KT, Richards PS, Ahuja AT. 2004. Frequency and determinants of poststroke dementia in Chinese. Stroke 35: 930-935.

* Tanzi RE. 2011. The genetics of Alzheimer disease. Cold Spring Harb Perspect Med doi: 10.1101/cshperspect. a006296.

* Tarawneh R, Holtzman DM. 2011. The clinical problem of symptomatic Alzheimer disease and mild cognitive impairment. Cold Spring Harb Perspect Med doi: 10.1101/ cshperspect.a006148.

Tervo S, Kivipelto M, Hanninen T, Vanhanen M, Hallikainen M, Mannermaa A, Soininen H. 2004. Incidence and risk factors for mild cognitive impairment: A population-based three-year follow-up study of cognitively healthy elderly subjects. Dement Geriatr Cogn Disord 17: 196-203.

Traber MG, van dV, Reznick AZ, Cross CE. 2000. Tobaccorelated diseases. Is there a role for antioxidant micronutrient supplementation? Clin Chest Med 21: 173.

Trichopoulou A, Costacou T, Bamia C, Trichopoulos D. 2003. Adherence to a Mediterranean diet and survival in a Greek population. New Engl J Med 348: 2599-2608.

Trujillo ME, Scherer PE. 2005. Adiponectin-journey from an adipocyte secretory protein to biomarker of the metabolic syndrome. J Intern Med 257: 167-175.
Tyas SL, Manfreda J, Strain LA, Montgomery PR. 2001. Risk factors for Alzheimer's disease: A population-based, longitudinal study in Manitoba. Int J Epidemiol 30: 590-597.

Tzourio C, Anderson C, Chapman N, Woodward M, Neal B, MacMahon S, Chalmers J. 2003. Effects of blood pressure lowering with perindopril and indapamide therapy on dementia and cognitive decline in patients with cerebrovascular disease. Arch Intern Med 163: 1069-1075.

Valenzuela MJ, Sachdev P. 2005. Brain reserve and dementia: A systematic review. Psychol Med 25: 1-14.

van Gelder BM, Tijhuis M, Kalmijn S, Kromhout D. 2007. Fish consumption, n-3 fatty acids, and subsequent 5-y cognitive decline in elderly men: The Zutphen Elderly Study. Am J Clin Nutr 85: 1142-1147.

van Praag H, Kempermann G, Gage FH. 1999. Running increases cell proliferation and neurogenesis in the adult mouse dentate gyrus. Nat Neurosci 2: 266-270.

Verghese J, Lipton RB, Hall CB, Kuslansky G, Katz MJ. 2003a. Low blood pressure and the risk of dementia in very old individuals. Neurology 61: 1667-1672.

Verghese J, Lipton RB, Katz MJ, Hall CB, Derby CA, Kuslansky G, Ambrose AF, Sliwinski M, Buschke H. 2003b. Leisure activities and the risk of dementia in the elderly. New Engl J Med 348: 2508-2516.

Waldstein SR, Katzel LI. 2006. Interactive relations of central versus total obesity and blood pressure to cognitive function. Int J Obes 30: 201-207.

Waldstein SR, Giggey PP, Thayer JF, Zonderman AB. 2005. Nonlinear relations of blood pressure to cognitive function: The Baltimore Longitudinal Study of Aging. Hypertension 45: 374-379.

Wang HX, Wahlin A, Basun H, Fastbom J, Winblad B, Fratiglioni L. 2001. Vitamin $\mathrm{B}(12)$ and folate in relation to the development of Alzheimer's disease. Neurology 56: $1188-1194$.

Wang HX, Karp A, Winblad B, Fratiglioni L. 2002. Late-life engagement in social and leisure activities is associated with a decreased risk of dementia: A longitudinal study from the Kungsholmen project. Am J Epidemiol 155: 1081-1087.

Wang L, Larson EB, Bowen JD, van Belle G. 2006. Performance-based physical function and future dementia in older people. Archiv Intern Med 166: 1115-1120.

Watson GS, Cholerton BA, Reger MA, Baker LD, Plymate SR, Asthana S, Fishel MA, Kulstad JJ, Green PS, Cook DG, et al. 2005. Preserved cognition in patients with early Alzheimer disease and amnestic mild cognitive impairment during treatment with rosiglitazone: A preliminary study. Am J Geriatr Psychiat 13: 950-958.

* Weintraub S, Wicklund AH, Salmon DP. 2011. The neuropsychological profile of Alzheimer disease. Cold Spring Harb Perspect Med doi: 10.1101/cshperspect.a006171.

Wen Y, Yang SH, Liu R, Perez EJ, Brun-Zinkernagel AM, Koulen P, Simpkins JW. 2007. Cdk5 is involved in NFT-like tauopathy induced by transient cerebral ischemia in female rats. Biochim Biophys Acta 1772: 473-483.

Wen Y, Yu WH, Maloney B, Bailey J, Ma J, Marie I, Maurin T, Wang L, Figueroa H, Herman M, et al. 2008. Transcriptional regulation of $\beta$-secretase by $25 / \mathrm{cdk} 5$ leads to 
enhanced amyloidogenic processing. Neuron 57: 680690.

White L, Katzman R, Losonczy K, Salive M, Wallace R, Berkman L, Taylor J, Fillenbaum G, Havlik R. 1994. Association of education with incidence of cognitive impairment in three established populations for epidemiologic studies of the elderly. J Clin Epidemiol 47: 363-374.

Whitehouse PJ, Martino AM, Wagster MV, Price DL, Mayeux R, Atack JR, Kellar KJ. 1988. Reductions in $\left[{ }^{3} \mathrm{H}\right]$ nicotinic acetylcholine binding in Alzheimer's disease and Parkinson's disease: An autoradiographic study. Neurology 38: 720-723.

Whitmer RA, Gunderson EP, Barrett-Connor E, Quesenberry CP Jr, Yaffe K. 2005a. Obesity in middle age and future risk of dementia: A 27 year longitudinal population based study. BMJ 330: 1360 .

Whitmer RA, Sidney S, Selby J, Johnston SC, Yaffe K. 2005b. Midlife cardiovascular risk factors and risk of dementia in late life. Neurology 64: 277-281.

Wijsman EM, Pankratz ND, Choi Y, Rothstein JH, Faber $\mathrm{KM}$, Cheng R, Lee JH, Bird TD, Bennett DA, Diaz-Arrastia R, et al. 2011. Genome wide association of familial late onset Alzheimer's disease replicates $B I N 1$ and $C L U$, and nominates CUGBP2 in interaction with APOE. PLoS Genet 7: e1001308.

Wilson RS, Bennett DA, Bienias JL, Aggarwal NT, Mendes De Leon CF, Morris MC, Schneider JA, Evans DA. 2002a. Cognitive activity and incident $\mathrm{AD}$ in a population-based sample of older persons. Neurology 59: $1910-1914$.

Wilson RS, Mendes De Leon CF, Barnes LL, Schneider JA, Bienias JL, Evans DA, Bennett DA. 2002b. Participation in cognitively stimulating activities and risk of incident Alzheimer disease. JAMA 287: 742-748.

Wilson RS, Scherr PA, Schneider JA, Tang Y, Bennett DA. 2007. Relation of cognitive activity to risk of developing Alzheimer disease. Neurology 69: 1911-1920.

Wilson RS, Barnes LL, Aggarwal NT, Boyle PA, Hebert LE, Mendes de Leon CF, Evans DA. 2010. Cognitive activity and the cognitive morbidity of Alzheimer disease. Neurology 75: 990-996.

Wright CB, Festa JR, Paik MC, Schmiedigen A, Brown TR, Yoshita M, DeCarli C, Sacco R, Stern Y. 2008. White matter hyperintensities and subclinical infarction: Associations with psychomotor speed and cognitive flexibility. Stroke 39: 800-805.

Wu C, Zhou D, Wen C, Zhang L, Como P, Qiao Y. 2003. Relationship between blood pressure and Alzheimer's disease in Linxian County, China. Life Sci 72: 1125-1133.

Yamada M, Kasagi F, Sasaki H, Masunari N, Mimori Y, Suzuki G. 2003. Association between dementia and midlife risk factors: The Radiation Effects Research Foundation Adult Health Study. J Am Geriatr Soc 51: 410-414.

Yamagishi S, Nakamura K, Inoue H, Kikuchi S, Takeuchi M. 2005. Serum or cerebrospinal fluid levels of glyceraldehyde-derived advanced glycation end products (AGEs) may be a promising biomarker for early detection of Alzheimer's disease. Med Hypoth 64: 1205-1207.

Yip AG, Brayne C, Matthews FE. 2006. Risk factors for incident dementia in England and Wales: The Medical Research Council Cognitive Function and Ageing Study. A population-based nested case-control study. Age Ageing 35: 154-160.

Yu YH, Ginsberg HN. 2005. Adipocyte signaling and lipid homeostasis: Sequelae of insulin-resistant adipose tissue. Circul Res 96: 1042-1052.

Zhang X, Li C, Zhang M. 1999. Psychosocial risk factors of Alzheimer's disease. Zhonghua Yi Xue Za Zhi 79: 335-338.

Zhou DH, Wang JY, Li J, Deng J, Gao C, Chen M. 2004. Study on frequency and predictors of dementia after ischemic stroke: The Chongqing stroke study. J Neurol 251: 421-427.

Zhu L, Fratiglioni L, Guo Z, Basun H, Corder EH, Winblad B, Viitanen M. 2000. Incidence of dementia in relation to stroke and the apolipoprotein $\mathrm{E} \varepsilon 4$ allele in the very old. Findings from a population-based longitudinal study. Stroke 31: 53-60. 


\section{$\&_{\mathrm{CSH}}^{\infty} \&$ Cold Spring Harbor \\ $\stackrel{\text { PERSPECTVES }}{+\infty}$ Perspectives in Medicine}

\section{Epidemiology of Alzheimer Disease}

Richard Mayeux and Yaakov Stern

Cold Spring Harb Perspect Med 2012; doi: 10.1101/cshperspect.a006239 originally published online April 10,2012

Subject Collection The Biology of Alzheimer Disease

Animal Models of Alzheimer Disease

Frank M. LaFerla and Kim N. Green

Neurovascular Dysfunction and Faulty Amyloid $\beta$

-Peptide Clearance in Alzheimer Disease

Abhay P. Sagare, Robert D. Bell and Berislav V. Zlokovic

Treatment Strategies Targeting Amyloid $\beta$-Protein Dale Schenk, Guriqbal S. Basi and Menelas N. Pangalos

The Ubiquitin-Proteasome System and the Autophagic-Lysosomal System in Alzheimer Disease

Yasuo Ihara, Maho Morishima-Kawashima and Ralph Nixon

Neurotoxicity of Amyloid $\beta$-Protein: Synaptic and Network Dysfunction Lennart Mucke and Dennis J. Selkoe

Proteolytic Degradation of Amyloid $\beta$-Protein Takaomi Saido and Malcolm A. Leissring

Brain Imaging in Alzheimer Disease Keith A. Johnson, Nick C. Fox, Reisa A. Sperling, et al.

Symptomatic and Nonamyloid/Tau Based Pharmacologic Treatment for Alzheimer Disease Paul S. Aisen, Jeffrey Cummings and Lon S. Schneider
Alzheimer Disease in 2020

David M. Holtzman, Eckhard Mandelkow and

Dennis J. Selkoe

The Genetics of Alzheimer Disease Rudolph E. Tanzi

Fluid Biomarkers in Alzheimer Disease

Kaj Blennow, Henrik Zetterberg and Anne M. Fagan

Epidemiology of Alzheimer Disease

Richard Mayeux and Yaakov Stern

Biochemistry and Cell Biology of Tau Protein in Neurofibrillary Degeneration

Eva-Maria Mandelkow and Eckhard Mandelkow

Biochemistry of Amyloid $\beta$-Protein and Amyloid

Deposits in Alzheimer Disease

Colin L. Masters and Dennis J. Selkoe

The Neuropsychological Profile of Alzheimer

Disease

Sandra Weintraub, Alissa H. Wicklund and David P.

Salmon

Apolipoprotein E and Apolipoprotein E Receptors:

Normal Biology and Roles in Alzheimer Disease

David M. Holtzman, Joachim Herz and Guojun Bu

For additional articles in this collection, see http://perspectivesinmedicine.cshlp.org/cgi/collection/ 